\title{
Prevalence of urinary schistosomiasis in Nwan a rural community in Akoko - Edo local government area, Edo state, Nigeria
}

\author{
Imarenezor, E.P.K ${ }^{1 *}$, Nmorsi, O.P.G ${ }^{2}$, Eghafona, N. O $^{3}$, Ohenhen, R. E ${ }^{1}$, Ekozien, M. I ${ }^{1}$, \\ ${ }^{I}$ Tropical Diseases Research Unit, Department of Microbiology, Ambrose Alli University, Ekpoma, Nigeria \\ ${ }^{2}$ Department of zoology, Ambrose Alli University, Ekpoma, Nigeria \\ ${ }^{3}$ University of Benin, Benin City, Nigeria \\ *Corresponding author E-mail: kimarenezor @ yahoo.com
}

\begin{abstract}
The prevalence of urinary schistosomiasis in Enwan, a rural community of Edo state, Nigeria was study with a total of 300 individuals volunteering to take part in the investigation for the present of Schistosoma haematobium ovas in their urine samples. Of this total samples which comprises of $193(64.3 \%)$ males and 107 (35.7\%) females examined for the presence ova of $S$. haematobium in their urine using centrifugation technique, overall, 130 (43.3\%) had the eggs of $S$. haematobium in their urine and which was graded as light infection $(<50 \mathrm{ova} / 10 \mathrm{ml})$ and heavy infection $(\geq 50$ ova $/ 10 \mathrm{ml})$ of urine. A total of $75(57.7 \%)$ had light infection while $55(42.3 \%)$ had heavy infection for S. haematobium. Thirty one $(37.3 \%)$ had heavy infection while $52(62.7 \%)$ light infection of $83(63.9 \%)$ positive males for $S$. haematobium. Twenty four (51.1\%) had heavy infection while $23(48.9 \%)$ had light infection of $47(36.1 \%)$ positive females for $S$. haematobium. Males had the highest to the lowest prevalence rate at age between $16-20$ years $37(71.2 \%), 26-30$ years $17(44.7 \%), 11-15$ years $13(30.2 \%)$ and $21-25$ years $16(26.7 \%)$ in that order, Females had the highest to the lowest prevalence rate at age 11 - 15years 6(66.7\%), 16 -20years 25(62.5\%), 21 - 25years 10(33.3\%) and 26 - 30years $6(21.4 \%)$ in that order. Male's prevalence rate when compared to that of female showed no significant difference in the surveyed population.
\end{abstract}

Keywords: Urinary schistosomiasis, prevalence, rural community, Nigeria.

\section{Introduction}

Urinary schistosomiasis caused by fluke worm Schistosoma haematobium is one of the most common tropical diseases which poses serious health hazard due to its associated morbidities. Globally, over 153 million are infected with this parasitic infection [28]. In Nigeria, pocket of foci of infections have been documented in various part of country [12, 1, $3,26]$.

In developing nations, the true epidemiological picture appears difficulty because of inadequate researchers in this direction despite its relevance in planning it control in any locality. This problem is compounded by the poor habits of people in developing countries like Nigeria in visiting hospitals for treatment. Also self-medication is still practiced as manifested by antihelminathics abuse.

This act is worsened by presence of inadequate health facilities. One of the consequences of the self-medication and antihelminathics abuse includes the suppression of the egg laying capacity of the worms. The net effect is erroneous diagnosis using oval in urine in any locality. This may also become evidence in sub clinical cases and period of immaturity of the worms when they are yet to commence egg laying. Another obvious difficulty occurs during very low grade infections. Although the uses of serological diagnosis are available, poverty poses a major serious impediment to the applications of serology in the epidemiological work in these countries.

To this end, this paper tends to evaluate the prevalence rate urinary schistosomiasis in an endemic community like Enwan which will broaden the existing epidemiological picture of this parasitic infection in this part of the globe and has a direct consequence on planning adequate control programme. 


\section{Materials and methods}

\subsection{Study area}

The study area is Enwan in Akoko Edo local government area of Edo state, Nigeria. It lies $7^{0} \mathrm{~N}$ and longitude $6^{0} \mathrm{E}$. The community has a functional health centre which was used for the collection of samples. The community has estimated population size of 2000 inhabitants. Farming and hunting is their predominant activities while few of them (villagers) mostly women are traders. There are streams which the inhabitants use as their source of water for domestic purpose and for recreational activities.

\subsection{Study population (individuals)}

A total of 300 volunteers were recruited for this study. Their ages range between 11-30 years old. History and general body examination were taken to exclude individuals with allergy and skin infections. Also appropriate parasitological and bacteriological investigations/diagnosis was carried out to exclude other parasitic infections such as malaria, hookworm, urinary tract infection etc. the history of self medication and their contract with the water bodies in the locality which are infected with snail intermediate hosts were taken.

The individuals were enlightened on the relevance of the study especially the public health significance. After the community mobilization, the mid stream urine of individuals were collected after a physical exercises of about 20 to 30 minutes. These urine samples were transported to research laboratory of department of Microbiology, Ambrose Alli University, Ekpoma for further procession.

\section{Results}

A total of 300 urine samples collected from the individuals in Enwan community, Akoko - Edo Local Government Area were examined, of the Three hundred (300) samples examined, 130 (43.3\%) were positive for S. haematobium infection of which $83(63.9 \%)$ were males and $47(36.1 \%)$ were females. Males had the highest to the lowest prevalence rate at age between 16 - 20years 37(71.2\%), 26 - 30 years 17(44.7\%), 11 - 15years 13(30.2\%) and $21-25$ years $16(26.7 \%)$ in that order, Females had the highest to the lowest prevalence rate at age $11-15$ years $6(66.7 \%)$, $16-$ 20years 25(62.5\%), 21 - 25years 10(33.3\%) and 26-30years 6(21.4\%) in that order (Table 1).

The investigation of Intensity of infection of urinary schistosomiasis in the study population showed 130(43.3\%) of the study population investigated had the ova of Schistosoma haematobium in their urine samples. Seventy - five (57.7\%) had light infection for ova of S. haematobium while 55(42.3\%) had heavy infection for ova of S. haematobium. Eighty three $(63.9 \%)$ positive males examined, 31(37.3\%) had heavy infection for ova S. haematobium while 52(62.7\%) had light infection for ova of S. haematobium. Forty - seven (36.1\%) positive females was examined, 24(51.1\%) had heavy infection for ova of S. haematobium while 23(48.9\%) had light infection for ova of S. haematobium respectively (Table 2).

Table 1: Prevalence of urinary schistosomiasis in the study population.

\begin{tabular}{|c|c|c|c|c|c|c|}
\hline AGE (Years) & \multicolumn{2}{|c|}{ MALE } & \multicolumn{2}{|c|}{ FEMALE } & \multicolumn{2}{|c|}{ Total } \\
\hline & $\begin{array}{c}\text { No. } \\
\text { examined }\end{array}$ & $\begin{array}{c}\text { No. } \\
\text { Infected }(\%)\end{array}$ & $\begin{array}{c}\text { No. } \\
\text { examined }\end{array}$ & $\begin{array}{c}\text { No. } \\
\text { Infected }(\%)\end{array}$ & $\begin{array}{c}\text { No. } \\
\text { examined }\end{array}$ & $\begin{array}{c}\text { No. } \\
\text { Infected }(\%)\end{array}$ \\
\hline $11-15$ & 43 & $13(30.2)$ & 9 & $6(66.7)$ & 52 & $19(36.5)$ \\
\hline $16-20$ & 52 & $37(71.2)$ & 40 & $25(62.5)$ & 92 & $62(67.4)$ \\
\hline $21-25$ & 60 & $16(26.7)$ & 30 & $10(33.3)$ & 90 & $26(28.9)$ \\
\hline $26-30$ & 38 & $17(44.7)$ & 28 & $6(21.4)$ & 66 & $23(34.9)$ \\
\hline TOTAL & 193 & $83(63.9)$ & 107 & $47(36.1)$ & 300 & $130(43.3)$ \\
\hline
\end{tabular}

Table 2: Intensity of infection, quantified as $<50 \mathrm{ova} / 10 \mathrm{ml}$ (light infection) and $\geq 50 \mathrm{ova} / 10 \mathrm{ml}$ (heavy infection) of urine.

\begin{tabular}{|c|c|c|}
\hline Sex/Total No & Light infection $<50 \mathrm{ova} / 10 \mathrm{ml}$ urine & Heavy infection $\geq 50 \mathrm{ova} / 10 \mathrm{ml}$ urine \\
\hline Male 83 & $52(62.7 \%)$ & $31(37.3 \%)$ \\
Female 47 & $23(48.9 \%)$ & $24(51.1 \%)$ \\
Total 130 & $75(57.7 \%)$ & $55(42.3 \%)$ \\
\hline
\end{tabular}




\section{Discussion}

The results of this study revealed the prevalence pattern and intensity of S. haematobium in Enwan. The prevalence of urinary schistosomiasis (S. haematobium) was $43.3 \%$. This indicated hyperendemencity of infection in Enwan. The rate supports the values reported by [19] but appeared higher than that of the earlier reports of [8, 9] at the same geographical region. From the 130(43.3\%) positive samples, it was found that $83(63.9 \%)$ males and $47(36.1 \%)$ females were infected; this could be as result of both males and females have been exposed to the water bodies which is a main source of the infection irrespective of sex $[27,15,20)$ Male had the highest prevalence rate at age between $16-$ 20 years $37(71.2 \%)$, the reason for this prevalence rate of male infected within the age 16-20years 37(71.2\%) is that, it is at this age group males engage actively in social cultural activities $[18,17,12)$. Females had the highest prevalence rate at age $11-15$ years 6(66.7\%). Prevalence rate is highest in females infected at ages $11-15 y e a r s$ 6(66.7\%) and $16-$ 20 years $25(62.5 \%)$ due to females engagement more in domestic chores at this age [11, 6]. In comparison, it will be noted that prevalence rate of $S$. haematobium in both males and females is at its peak at ages between $11-15 y e a r s$ and 16 - 20years as result of their exposure to the water bodies infected with this parasite irrespective of their sex [3, 19, 9, $5,1]$. The pattern of infection showed that fewer individuals had heavy infection with S. haematobium. This contradicts the earlier report of [21] in the same zoogeographic zone. Over $75 \%$ of the S. haematobium infections in our studied locality occurred in volunteers that were $11-25$ years of age. Similar observations had been documented earlier [22]. The rate of prevalence of urinary schistosomiasis in this present study reflects the dependence of inhabitants on the infected water bodies. This is in agreement with report of past studies of S. haematobium endemic area [7, 12, 20). Also, the high rate of infection reported in this investigation may be suggestive of the level of S. haematobium transmission in various foci in the community. The running stream and burrow pits are the main transmission foci in the community which are distributed all over the place. They provide a natural water source as well as serve as meeting point for the schistosome parasites, their intermediate host and the people. The people depend on these ponds for fishing, bathing and other domestic needs hence; ensure that the people continue being affected, infected and re - infected since no intervention strategy has been put in place in the area.

Comparatively, the high infection among males may have resulted from their preponderance in the survey and may not have been due to over exposure to the infection site. The variations in the infection pattern may be attributed to differences in geographical and environmental setting, cultural and religious beliefs in each endemic area [3]. Although there are some reported cases of higher male infection than the females in some studied endemic areas [14, 13, 2]. Some other studies have found no significant differences in gender prevalence [16].

Intensity of infection which was based on eggs count per $10 \mathrm{ml}$ of urine sample obtained from the volunteers, showed that egg counts rose with decreasing years and reduced with increasing years, thus, showing a negative correction. This is in agreement with results of intensity studies in other $S$. haematobium endemic areas [10]. Comparatively this rate was higher than those reported by [24] and [23] but was in agreement with report by [18] which report that $S$. haematobium ova counts is higher in active individuals which also collaborate the report of $[29,17,12]$ that as infection and re - infection occur more eggs of S. haematobium are produced with active individuals ages between $16-20$ years and decreases as the infected individuals becomes less active with social cultural activities. This investigation will broaden the known foci of urinary schistosomiasis in Nigeria which is invaluable in planning control programme for urinary schistosomiasis in this part of the globe.

\section{References}

[1] G. O. Adeoye and Akabogu O.A.S .Occurrence of urnary schistosomiasis among residents of Ado-Odo/ota area of Ogun state, Nigeria. The Nig. J. Parasit 1996 17:23-30.

[2] A. O. Adeyeba and Ojeaga, S. G. T. . Urinary schistosomiasis and concomitant urinary tract pathogens among school children in Metropolitan Ibadan, Nigeria. Afr. J. Biomed Res.2002 5: $103-107$.

[3] B. O. Akogun and Obadiah S. Occurrence of urinary schistosomiassis among residents of Ado-Odo/Ota area of Ogun state Nigeria. The Nig. J. Parasit 1996a 17:23-30.

[4] B. O. Akogun and Obadiah S. History of haematuria among school-aged children for rapid community diagnosis of urinary schistosomiasis. The Nig. J. Parasit 1996b 17:11-15.

[5] A. A. Akonai, Ijaware C.O and Okon E.E. Urinary schistosomiasis in southern Nigeria. J. Med. Lab. Sci. 1992 2:12-16.

[6] W. P. Arewa. The balance between IL - 1 and IL - Ra in disease cytokine growth factor. Review. 2003 13: $323-340$.

[7] J. C. Anosike, Okafor F.C and Onwuliri C.O.E, Urinary schistosomiasis in Toro local government area of Bauchi State, Nigeria. Helminthologia 1992. 29:177-179.

[8] G. O. Arinola. Immunological Aspects of Urinary Schistosomiasis in Ibadan, Southwestern Nigeria. Annals of Ibadan Postgraduate Medicine. 2005 3: 1-15

[9] G. O. Arinola and Salimonu, L. S. Anthropometric parameter and haematological parameters in relation to severity of urinary schistosomiasis among Nigeria primary school children. Journal Sciences, Engineering and Technology.2000 6: 3 -7.

[10] A. B. Bello and Edungbola, L.D. Schistosoma haematobium, a neglected common parasitic disease of childhood in Nigeria: Study of incidence and intensity of infection. Acta Paediatr. 1992 81: 601-604. 
[11] A. Chihaka, Molgaad, P. and Hemminocoh, E. Biodegrability of molluscidal saponins of phytolocca Jodecandal Ragal. Toxicology and Pharmacology. 2000 32: $248-255$.

[12] A. O. Egwunyenga, Nmorsi P.and Omokaiye O.O. Schistosomiasis in Bauchi, Nigeria. The Nig. J. Parasit 1994 15:35-41.

[13] S. Elite. Interaction of schistosoma eggs with vascular endothelium. Journal of parasitology.1995 5: $234-238$.

[14] A. I. Eltoum, Suliaman S.M, Ismail B.M, Ali M.M, Elfatih M and Homeida M.M. Evaluation of haematuria as an indirect screening test for schistosomiasis: a population based study in the vhilte niles province sudan. Acta tropical 1992 151:151-157.

[15] K. F. Hoftman, Wynn, T. A. and Dunne, D. W. Cytokine - mediated host responses during schistosoma infection; walking the time line between immunological control and immunopathology. Advance parasitology. 2002 52: 265 - 266.

[16] L. H. Hogan, Wang, M., Suresh, M., Weinstock, J. V. and Sandor, M. CD4+ TCR repertoire heterogeneity in Schisosoma mansoni induced granulomas. J. Immunol. 2002 169: 6386 - 6393.

[17] K. W. Moore, Dewealmalefat, R. C. and Coftman, A. W. Interleukin - 10 and interleukin - 10 receptor. Annual review immunology. 2001 19: $683-684$.

[18] F. Mutapi, Ndhlovu, P.O, Hagan .P, Spicer .J.T, Mduhiza .T, Turner C. M, and Chandiwanark, J. Chemotherapy Accelerates the Development of Acquired Immune Response to Schistosoma haematobium Infections. Journal of Infections Diseases. 1998. 178: 289-293.

[19] O.P.G. Nmorsi, Egwunyenga O.A Okolo O. Schistosoma haematobium infections in two rural communities in Edo state, Nigeria. South East Asia J. trop. Med. Public health. 2001a 32 (3): 570-574.

[20] O.P.G. Nmorsi, Egwunyenga O.A, Bajomo D.O. A survey of urinary schistosomiasis and trichomoniasis in a rural community in Edo state, Nigeria. Acta medica et Biologica 2001b 49 (1): 25-29.

[21] O.P.G. Nmorsi, Ukwandu, N. C., Ogoinja , S., Blackie, H. O and Odike, M. A. Urinary tract pathology in Schistosoma haematobium infected rural Nigerians. Southeast Asian Journal of Tropical Medicine and Public Health. 2007 38(1): $32-37$.

[22] E.L. Okoli and Odiabo, A.B. Urinary Schistosomiasis Among School Children in lbadan, an urban community in South western Nigeria. Tropical Medicine International Health. 1999 4:308-315.

[23] A.O. Remme, Jan H. F, Raadt, D. P and Godal T. The Burden of Tropical Disease. The Medical Journal Australia. 2002157 (7): $465-469$.

[24] L. Savioli, Renganathan, E., Montresor, A., Davis, A., Behbeheni, K. Control of Schistosomiasis, a global picture. Parasitology Today 1997 13: 444-448.

[25] N.C.D. Ukwandu and Nmorsi, O. P. G. The perception, beliefs and practices toward genitourinary schistosomiasis by inhabitants of selected ,endemic areas (Edo/Delta States) of south - Eastern Nigeria. Rev. Inst. Med. Trop. S.Paulo. 200446 (4): 209 - 216.

[26] M.F. Useh and Ejezie G.C Prevalence and morbidity of Schistosoma haematobium in Adam community of Nigeria. J. med. Lab. Sci. 1996 5:21-25.

[27] K. S. Warren. Schistosomasis: Host-pathogen biology. Review of Infection Disease 2007 4: 771-5.

[28] WHO. Report of the WHO informal consultation of schistosomiasis control. Geneva December WHO/CDS/CPC/SIP/99.2 2007

[29] M.E.J. Woolhouse, Taylor P., Matanhire D., Chandiwana S.K .Acquired immunity and the epidemiology of Schistosoma haematobium. Nat. 1991 351:757-759. 